\title{
Anti-obesity Effects of Mulberry Leaf and Yacon Extract in Obese Rats
}

\author{
Yong Lim ${ }^{1, *}$, Ji Hye $\mathrm{Oh}^{2, * *}$, Un Kyu Park ${ }^{2, * *}$, Man Kyu Huh ${ }^{3, *}$ and Seock-Yeon Hwang, ${ }^{2, \dagger ; *}$ \\ ${ }^{1}$ Department of Clinical Laboratory Science, Dong-eui University, Busan 47340, Korea \\ ${ }^{2}$ Department of Biomedical Laboratory Science, Daejeon University, Daejeon 34520, Korea \\ ${ }^{3}$ Food Engineering and Technology Major, Dong-eui University, Busan 47340, Korea
}

We evaluated the effect of anti-obesitic activity of MYE (mulberry leaf + Yacon tuber) extracted from Morus alba as muberry leaf and Smallanthus sonchifolia as yacon. 1\%, 3\%, or 5\% of MYE were treated to Sprague-Dawley rats exposed to a high-fat diet. MYE treated rats were suppressed weight during four weeks, and they lost weight significantly after six weeks. Common blood chemistry panels related to liver function revealed significant improvement in the MYE-treated groups. The expression of leptin as indicators for obesity was decreased in perirenal fat. Such results indicate that MYE could be a promising candidate for the improvement of obesity. In addition, MYE effected on deceased glucose metabolism, reducing the activities of glucose-6-phosphate dehydrogenase (G-6-PDH) and glucokinase related to glycogen synthesis. The fatty liver was observed in high-fat diet-treated rats, resulting from increased number of adipose cells and Ito cells. However, this pathologic change was significantly improved by administration of MYE. MYE have significant effects on antioxdative function and glycometabolism against high fat diet. Thereby, it seems that MYE prevent fatty liver by high-fat diet. Thus it is suggested that MYE would be worth being developed as an biofunctional food to prevent undesirable effects caused by obesity.

Key Words: Glucose-6-phosphate dehydrogenase (G-6-PDH), Leptin, Muberry leaf, Obesity, Yacon

\section{서 론}

비만은 건강에 유해한 영향을 미칠 정도로 체내에 지 방이 과다하게 축적되는 것으로 정의되며(Ogden et al., 2007), 그 원인은 유전적, 생리적, 요인과 관련이 있다 (Prentice, 2001). 일반적으로 비만은 일차성 비만과 이차성 비만으로 나누어지는데, 일차성 비만은 에너지 섭취량이 에너지 소모량보다 많은 상태에서 체지방이 증가하여 발 생하며, 이차성 비만은 유전, 내분비 질환, 약제 등에 의 해 발생한다. 이 중 일차성 비만은 전체의 $90 \%$ 이상으 로 대다수의 비만이 이에 해당된다. 세계보건기구(World
Health Organization, WHO)는 비만의 유병률이 1980년에 비 해 2008년 전세계적으로 거의 두 배 증가하였고, 유럽 여 성의 $23 \%$, 남성의 $20 \%$ 가 비만이라고 발표하였다(Ogden et al., 2007). WHO는 비만을 질병으로 선언하였고, 멀지 않아 미국 뿐만 아니라 한국을 비롯한 아시아 국가들에 게도 비만에 직면할 것이라고 발표하였으며(WHO, 2000), 실제로 한국인 성인 비만율은 2017년에 $25.9 \%$ 이었다 (Ministry of Health and Welfare, 2018).

비만은 독립적으로, 혹은 당뇨나 심혈관 질환 등 다 른 질환과 연관되어 많은 건강관련 문제를 야기시켜 (Kopelman, 2007), 비만으로 인한 당뇨병, 심혈관 질환의 발병률은 연령, 성별, 인종에 관계없이 지속적으로 증가

Received: March 6, 2020 / Revised: May 10, 2020 / Accepted: May 12, 2020

*Professor, ${ }^{* *}$ Graduate student.

${ }^{\dagger}$ Corresponding author: Seock Yeon Hwang. Department of Biomedical Laboratory Science, Daejeon University 62 Daehak-ro, Dong-gu, Daejeon 34520, Korea.

Tel: +82-42-280-2802, Fax:+82-42-280-2904, e-mail: syhwang@dju.kr

(C) The Korean Society for Biomedical Laboratory Sciences. All rights reserved.

(9) This is an Open Access article distributed under the terms of the Creative Commons Attribution Non-Commercial License (http://creativecommons.org/licenses/by-nc/3.0/) which permits unrestricted non-commercial use, distribution, and reproduction in any medium, provided the original work is properly cited. 
하고 있다(Kereiakes and Willerson, 2003; Jee et al., 2006). 비 만은 암, 뇌졸중, 심혈관 질환, 고혈압, 당뇨병성 당뇨증 (인슐린 의존성과 비인슐린 의존성) 등 1 차 질환과 2 차 질환도 유발할 수 있다(Pi-Sunyer, 1993). 따라서 비만 환 자에 대해 만성 질환의 진행을 막기 위한 각종 처방과 예방조치가 시행되고 있다. 비만을 위한 식이요법과 예방 법으로 비만도, 운동, 저칼로리 식단에 따라 소량의 섭취 와 식욕억제제 복용량이 제시되고 있으며, 심한 경우에는 소장의 위와 우회수술이 도입되고 있다(Atkinson, 1997; Carmichael, 1999; Weledji, 2016). 그러나 약물 치료법은 철 분 결핍과 그에 따른 빈혈을 유발할 수 있으며, 보통 체 내의 철분흡수 장애가 원인이 되는 여러 질병이 될 수 있다는 지적이 있었으며 각종 미네랄과 비타민, 보충제 를 받은 환자에도 불구하고 철분 부족을 막을 수 없었다 (Guallar et al., 2013). 이와 같이 약물 치료 성공률이 낮다 는 점과 부작용의 위험성이 공존한다는 점을 고려할 때 비만을 감소시키기 위해 자연 물질로부터 활성적이고 안 전한 성분을 찾는 것도 한 방안이 될 수 있다.

뽕나무(Morus alba L.)는 뽕나무과(Moraceae)에 속하는 관목으로 잎을 약재로 사용할 경우에 한약재명은 상엽 (桑葉), 줄기의 약재는 상지(桑枝), 열매는 상심자(桑椹子), 뿌리껍질은 상백피(桑白皮)라고 한다. 뽕잎에는 아미노산, 플라보노이드, 무기염류, 비타민 등이 함유되어 지방 과 산화, 콜레스테롤, 동맥경화, 고지혈증 등의 대사 질환을 억제하는 것으로 알려져 있다(Fujjmoto and Nomura, 1985). 야콘(Smallanthus sonchifolius (Poepp \& Endl) H. Robinson)은 페루의 안데스 산맥에서 자라는 다년생 초본이다. 야콘 (yacon)의 뿌리에는 다량의 fructo-oligosaccharide가 함유되 어 있어 항산화, 고지혈증 저해작용이 알려져 있고(Russo et al., 2015), 변비를 예방 및 완화, 혈액 지질과 혈당을 줄 여 당뇨병을 예방하여 환자 식단에 도움이 되며(Chen et al., 2000), 비만, 동맥경화증 및 당뇨로 인해 비흡수성 및 체내 미사용 물질을 제거한다(Kim, 2005).

본 연구의 예비조사와 실험에서 비만에 미치는 뽕잎과 야콘의 영향을 판단하기 위한 각종 주요 지표를 평가한 결과 비만에 대한 척도에서 긍정적인 영향을 나타내었다 $(\mathrm{Lim}, 2015)$. 따라서 본 연구에서 상엽과 야콘 추출물의 비율에 따라 쥐의 비만이 경감되는 정도가 유의미한 지 조사하였다. 본 연구 결과는 뽕잎과 야콘의 에탄올 추출 물을 이용한 비만 실험 지표에 도움이 될 수 있을 것이다.

\section{재료 및 방법}

\section{추출물의 준비}

뽕잎과 야콘은 대구 약령시장에서 시험 재료로 구입하 였다. 스테인리스 용기에 건조된 시험 물질(뽕잎과 야콘 각각 $1 \mathrm{~kg})$ 과 $50 \%$ 에탄올 $(10 \mathrm{~L})$ 을 넣고, $85^{\circ} \mathrm{C}$ 에서 8 시간 동안 시료를 추출한 후 냉각관으로 수집하였다. 한편, 동 일 무게의 건조 시료에 $70 \%$ 에탄올 $6 \mathrm{~L}$ 를 첨가하여 24 시 간 교반한 후 초음파세척기로 1시간 처리하여 두 번째 추출물을 추출했다. 이 두 추출물을 혼합한 후 회전형 감 압농축기로 농축한 후 동결건조기로 분말화하였다. 예비 시험에서 분말된 뽕잎과 야콘 추출물의 두 가지 다른 비 율을 혼합하여 비만에 가장 효과적인 비율을 산출하였고, 뽕잎과 야콘을 7:3의 비율로 섞은 것이 시너지 효과가 높 아 본 연구에 사용하였다.

\section{실험동물과 먹이}

본 실험에 사용된 쥐는 100 150 g 수컷 Sprague-Dawley (SD)으로 $\mathrm{DBL} \operatorname{Ltd}($ 충청북도 음성)에서 구입했다. 구입한 쥐는 7일 동안 사육 환경에 순치시켰고, 실험에는 건강한 동물들만 사용하였다. 동물들은 에어컨과 온풍기로 온도 $23 \pm 2{ }^{\circ} \mathrm{C}$, 가습기로 상대 습도 $(50 \pm 5 \%)$ 및 조명장치로 12 시간 명/암 주기로 사육하였다. 각각의 쥐들은 별도의 사육상자에서 먹이를 섭취하도록 관리하였다. 먹이 외 수 분은 증류수로 쥐에게 제공되었다.

쥐들은 여섯 그룹으로 나누고, 각 그룹당 10 마리씩 배 분하였다: G1: 정상군(normal diet group), G2: 고지질군(high fat diet group, HFD), G3: 양성 대조군(고지질 $+0.5 \%$ 하이 드록시시트릭산(high fat diet group with $0.5 \%$ hydroxycitric acid (HFD + HCA), G4: 1\% 처리군(high fat diet with 1\% mulberry leaf and yacon diet group, HFD + 1\% MYE), G5: 3\% 처리군(high fat diet with 3\% mulberry leaf and yacon group, $\mathrm{HFD}+3 \% \mathrm{MYE}), \mathrm{G} 6: 5 \%$ 처리군(high fat diet with 5\% mulberry leaf and yacon group, HFD $+5 \%$ MYE).

쥐는 체중이 정상 범위의 $30 \%$ 이상이 될 때까지 4 주 동안 고지방 식이요법으로 비만을 유도한 후 각 그룹별 로 옮겨 4주 동안 실험 물질을 먹였다. 정상 그룹 및 고 지방 먹이 그룹은 목적으로 한 구성물(AIN 93-M)을 제공 하였다(Table 1). 실험 그룹의 식단에서 정상 그룹의 총 에 너지 함량은 $4.25 \mathrm{kcal} / \mathrm{g}$ 이며 고지방 그룹은 총 에너지 함 량은 $5.20 \mathrm{kcal} / \mathrm{g}$ 이다. 양성대조군 $\mathrm{G} 3$ 그룹은 $0.5 \%$ 의 수산 
Table 1. Composition $(\mathrm{g} / \mathrm{kg})$ of the experimental diets for treatment groups

\begin{tabular}{lcrrrrr}
\hline \hline Constituent & G1 & G2 & G3 & G4 & G5 & G6 \\
\hline Casein & 200 & 200 & 200 & 200 & 200 & 200 \\
Maize starch & 521 & 321 & 321 & 321 & 321 & 321 \\
Sucrose & 100 & 100 & 100 & 100 & 100 & 100 \\
Maize oil & 100 & 100 & 100 & 100 & 100 & 100 \\
Lard & - & 200 & 200 & 200 & 200 & 200 \\
Cellulose & 30 & 30 & 30 & 30 & 30 & 30 \\
DL-methionine & 2 & 2 & 2 & 2 & 2 & 2 \\
Mineral mix ${ }^{\mathrm{a}}$ & 35 & 35 & 35 & 35 & 35 & 35 \\
Vitamin mix & 10 & 10 & 10 & 10 & 10 & 10 \\
Choline & 2 & 2 & 2 & 2 & 2 & 2 \\
bitartrate & & & & & & \\
$\begin{array}{l}\text { Gross energy } \\
\text { content (kcal/g) }\end{array}$ & 4.25 & 5.20 & 5.20 & 5.20 & 5.20 & 5.20 \\
\hline
\end{tabular}

HFD, high-fat diet. HCA, hydroxycitric acid. MYE, Mulberry leaf + yacon.

a) AIN mineral mixture $(\mathrm{g} / \mathrm{kg})$ : calcium phosphate dibasic 500 , sodium chloride 74 , potassium citrate 220 , potassium sulfate 52 , magnesium oxide 24 , manganous carbonate 3,5 , ferric citrate 6 , zinc carbonate 1,6 , cupric carbonate 0.3 , potassium iodate 0.01 , sodium selenate 0.01 , chrominium potassium sulfate 0.55

b) AIN vitamin mixture $(\mathrm{g} / \mathrm{kg})$ : thiamine $\mathrm{HCl} 0.6$, rivoflavin 0.6 , pyridoxine $\mathrm{HCl} 0.7$, niacin 3 , calcium pantothenate 1.6 , folic acid 0.2 , biotin 0.02 , vitamin B12 ( $0.1 \%$ trituration in mannitol) 1 , dry vitamin A palmitate $(500,000 \mathrm{U} / \mathrm{g}) 0.8$ dry vitamin $\mathrm{E}$ acetate $(500 \mathrm{U} / \mathrm{g}) 10$, vitamin $\mathrm{D}$, trituration $(400,000 \mathrm{U} / \mathrm{g}), 0.25$, mana dione sodium bisulfate complex 0.15

화지질산을 투여하였고, $\mathrm{G} 4 \sim \mathrm{G} 6$ 그룹은 $1,3,5 \% \mathrm{MYE}$ 의 고지방 식단을 제공하였다.

\section{체중, 음식, 물 소비량 측정}

쥐의 체중은 처리 전에 1 차로 측정하였고, 처리를 시작 한 후 2 주 동안 매일 세 번씩 측정하였으며, 처치 당일에 도 측정하였다. 2 주 동안 매일 식품과 물 소비량을 측정하 였으며, 일일 평균 식품 소비량 $(\mathrm{g} /$ 동물/일)도 계산하였다.

\section{부위별 체지방조직의 분석}

복강 내 표피 지방조직을 제거한 후 복막 지방조직과 중간 지방조직이 분리하여 무게를 측정하였다.

\section{지방조직 내 체지방, 체단백질, DNA 함량 측정}

시료 대상 동물을 처치 후 위장관(gastrocader)을 적출하 고 내부 내용물을 모두 제거하여 $105^{\circ} \mathrm{C}$ 에서 건조시킨 후 믹서기에 균질화했다. 시료는 체지방 및 단백질 함량 측
정에 사용하였으며, 시료 약 $20 \mathrm{~g}$ 으로 Oxhlet 추출법에 따 랐다. 체단백질 함량은 Kjeldahl 방법에 의한 무지질 시료 로 질소 함량을 측정한 후 질소 지수 6.25 를 적용해 계산 했다.

측간 갈색 지방조직(interscapular brown adipose tissue)의 단백질 함량은 균질화기에 $0.3 \mathrm{~N} \mathrm{NaOH}$ 를 첨가하여 동질 성에서 측정한 후 $45^{\circ} \mathrm{C}$ 에서 1 시간 동안 용해하였다. 단백 질의 함량은 Lowry et al. (1951) 방법으로 산출하였다. 8\% perchloric acid로 DNA를 추출하는 데 사용하였다. Diphenylamine 함량은 Burtion에 기술된 방법을 사용하여 측정 했다.

\section{당생성 측정}

글리코겐과 포도당 대사의 함량을 측정하기 위해 간 $2 \mathrm{~g}$ 을 $0.1 \mathrm{M}$ citrate butter (pH 4.2) $6 \mathrm{~mL}$ 로 균질화시키고, $3,000 \mathrm{rpm}$ 으로 10 분간 원심분리하였다. 글리코겐 함량과 포도당-6-인산염 탈수소효소(Glucose-6-Phosphate Dehydrogenase, G-6-PDH) 활성은 각각 Murat (1974)와 Hara (1986) 방법으로 측정하였다.

포도당-6-인산염(Glucose-6-phosphate dehydrogenase, G6-PD) 활성은 Baginski (1983) 방법에 의해 니코틴아마이 드 아데닌 다이뉴클레오타이드 인산(Nicotinamide adenine dinucleotide phosphate, NADP)로부터 포도당-6-인산염의 산 화로 생성된 $\mathrm{NADPH}$ 양을 분석하였다. 간 $2 \mathrm{~g}$ 은 $0.25 \mathrm{M}$ 자당 $15 \mathrm{~mL}$ 와 $0.5 \mathrm{M}$ EDTA로 처리하고, Teflon Potter Elvehjem을 사용하여 균질화하였다. 균질액을 $4{ }^{\circ} \mathrm{C}, 20,000$ $\times \mathrm{g}$ 에서 10 분간 원심분리하여, 미토콘드리아 상등액 내 $\mathrm{G}-6-\mathrm{PDH}$ 의 활성도를 측정하였다.

Glucokinase 활성은 DeMoss (1968) 방법에 따라 버터 혼 합물 $6 \mathrm{~mL}$ 로 처리된 간 $2 \mathrm{~g}$ 을 $1 \mathrm{mM} \mathrm{EDTA로} \mathrm{균질화하여}$ $12,000 \times \mathrm{g}$ 에서 1 시간 동안 원심분리한 후 상등액으로 glucokinase 활성을 측정하였다.

\section{혈청 내 렙틴 분석}

혈청 내 렙틴 함량은 렙틴 진단 키트(Animal Leptin RIA Kit, LINCO Research, Inc.)를 사용하여 Radioimmunoassay 방법으로 측정하였다.

\section{조직학적 평가}

병리학적 검사를 위해 먼저 동물을 처치하여 장기를 분 리하고 무게를 측정하였다. 적출된 장기는 $10 \%$ 의 중성 완충 포르말린으로 고정한 후 파라핀으로 포맷하여 $4 \mu \mathrm{m}$ 
Table 2. Effect of MYE on absolute organ weights in normal and high-fat diet-fed rats

\begin{tabular}{cccccc}
\hline \hline \multirow{2}{*}{ Treatment group } & \multicolumn{5}{c}{ Organ weight $(\mathrm{g})$} \\
\cline { 2 - 6 } & Liver & Lung & Kidney & Spleen & Testis \\
\hline G1 & $7.81 \pm 0.3$ & $1.80 \pm 0.5$ & $1.92 \pm 0.3$ & $0.78 \pm 0.12$ & $3.31 \pm 0.2$ \\
G2 & $7.46 \pm 0.2$ & $1.69 \pm 0.2$ & $1.89 \pm 0.2$ & $0.71 \pm 0.11$ & $3.22 \pm 0.3$ \\
G3 & $7.71 \pm 0.4$ & $1.67 \pm 0.3$ & $1.94 \pm 0.3$ & $0.71 \pm 0.11$ & $3.33 \pm 0.4$ \\
G4 & $7.85 \pm 0.5$ & $1.79 \pm 0.3$ & $1.88 \pm 0.3$ & $0.77 \pm 0.11$ & $3.33 \pm 0.2$ \\
G5 & $7.71 \pm 0.7$ & $1.84 \pm 0.6$ & $1.95 \pm 0.5$ & $0.85 \pm 0.15$ & $3.36 \pm 0.5$ \\
G6 & $7.85 \pm 0.8$ & $1.83 \pm 0.7$ & $1.93 \pm 0.5$ & $0.86 \pm 0.15$ & $3.41 \pm 0.5$ \\
\hline
\end{tabular}

두께로 절화하고, 헤마톡실린에오신(H \& E)으로 염색하여 조직을 현미경으로 검경하였다.

\section{통계분석}

데이터의 모든 숫자는 평균 \pm 표준 편차로 표시하였다. 통계적 유의성은 Duncan의 다중 범위 검사에 이어 일원 분산 분석(ANOVA)로 분석하였다. 유의성은 $P<0.05$ 수준 에서 판정하였다. 통계적 분석은 SPSS (Statistical Package for Social Sciences) 20.0 프로그램을 사용하였다.

\section{결 과}

\section{고지방 식이요법 쥐의 MYE가 신체 및 장기 체중 변화 에 미치는 영향}

시료 동물 그룹별 사육 후 4 주 동안 식이요법만 실시 하여 체중이 거의 일정하게 증가하였다. 특히 6 주 동안 고지방 먹이 섭취 그룹의 체중은 정상 대조군 $(\mathrm{Gl})$ 에 비해 $11 \%$ 증가했다 $(P<0.05)$ (Fig. 1). $\mathrm{HCA}$ 로 2주 처리한 전체 6 주에서 $\mathrm{G} 3$ 의 체중이 크게 증가하지 않았다 $(P>0.05)$. 그 러나 MYE 처리 후 2주 경과한 6 주에는 $1 \%, 3 \%, 5 \% \mathrm{MYE}$ 로 처리한 세 그룹의 체중은 치료 후 6 주, 8 주 동안 $\mathrm{G} 1$ 에 비해 크게 줄었다 $(P<0.05 \sim 0.01)$ 한편, 간, 폐, 신장, 고환 을 포함한 장기 무게에 있어서 그룹간 차이가 있었다 (Table 2). G1에 비해 G2의 5 개 장기 무게는 모두 감소하 였다. $\mathrm{G} 2$ 에 비해 $\mathrm{G} 3$ 및 $1 \%, 3 \%, 5 \% \mathrm{MYE}$ 처리군은 증가 하였고, 특히 G6그룹은 $\mathrm{G} 1$ 과 유사하였다.

고지방 식이 처리 쥐의 MYE가 체지방, 단백질, 에너지 소비에 미치는 영향

$\mathrm{G} 2$ 의 위 지방조직은 $\mathrm{G} 1$ 에 비해 $52.4 \%$ 증가하였다 $(P<$ 0.01 ) (Table 3). 그러나 $\mathrm{G} 2$ 에 비해 $1 \%, 3 \%, 5 \% \mathrm{MYE}$ 처리

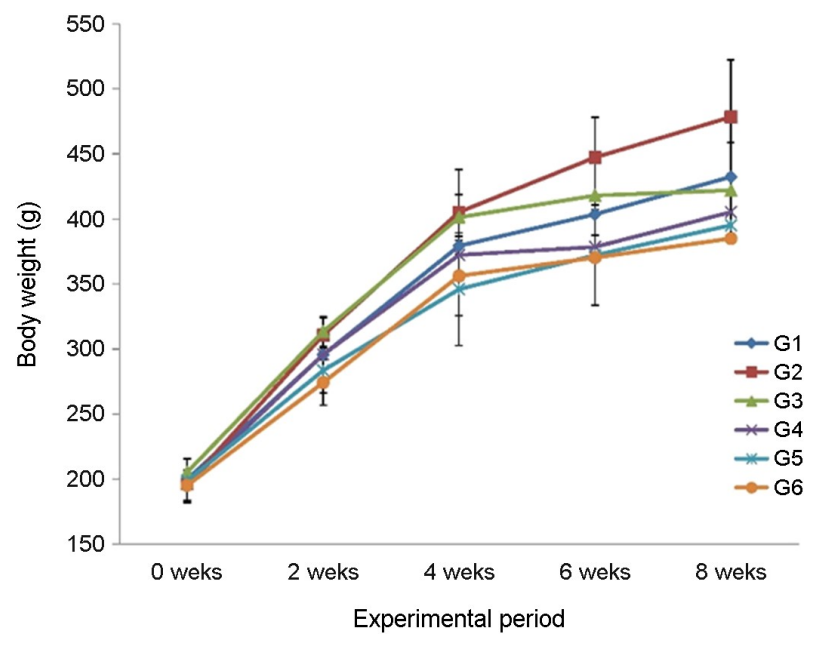

Fig. 1. Effect of MYE (mulberry leaf + yacon tuber) on body weight changes in high-fat diet-fed rats.

그룹은 $17.2 \%, 22.1 \%, 21.2 \%$ 감소하였다. 양성 대조군 $(\mathrm{G} 3)$ 은 $\mathrm{G} 2$ 에 비해 $25.3 \%$ 감소하였다 $(P<0.01) . \mathrm{G} 2$ 의 신장 지 방조직은 $\mathrm{G} 1$ 에 비해 $14.0 \%$ 증가하였다 $(P<0.05)$. 그러나 $\mathrm{G} 2$ 에 비해 $3 \%, 5 \% \mathrm{MYE}$ 그룹은 $8.7 \%, 8.5 \%$ 가 감소하였다 $(P<0.05) . \mathrm{G} 2$ 의 부정소 지방조직은 $\mathrm{G} 1$ 에 비해 $38.5 \%$ 증가 하였다 $(P<0.05)$. 그러나 $\mathrm{G} 2$ 에 비해 $3 \% \mathrm{MYE}$ 그룹과 $5 \%$ MYE 그룹에서는 각각 $20.3 \%, 22.6 \%$ 감소하였다 $(P<0.05)$. 장내 지방조직의 결과는 부정소 지방조직 $(P<0.05)$ 과 유사 하였다. $\mathrm{G} 2$ 의 갈색 지방조직(BAT)은 $\mathrm{G} 1$ 보다 1.3 배(31.3\%) 증가하였다 $(P<0.05)$. 특히, $\mathrm{G6}$ 그룹은 $\mathrm{G} 2$ 과 비교하여 $7.9 \%$ 로 감소하였다.

체지방에 대해 $\mathrm{G} 2$ 는 $55.1 \mathrm{~g}$ 으로 $\mathrm{G} 1$ 의 $39.6 \mathrm{~g}$ 에 비해 $41.8 \%$ 증가하였다(Table 4). 처리군(G4 G6)은 고지방군에 비해 $11.0 \sim 27.4 \%$ 감소하였다. 그러나 체단백질은 유의미 한 변화가 관찰되지 않았다. DNA 농도는 정상군에 비해 
Table 3. Effect of MLYE (mulberry leaf + yacon tuber) on organ fats in normal and high-fat diet-fed rats (unit: g)

\begin{tabular}{cccccc}
\hline \hline Treatment group & Stomach fat & Perirenal fat & Epididymal fat & Visceral fat & BAT \\
\hline G1 & $8.13 \pm 1.26$ & $7.65 \pm 1.14$ & $5.54 \pm 1.19$ & $5.26 \pm 0.90$ & $1.12 \pm 0.12$ \\
G2 & $12.39 \pm 1.35^{\mathrm{b}}$ & $8.72 \pm 1.10^{\mathrm{a}}$ & $7.67 \pm 2.36^{\mathrm{a}}$ & $6.88 \pm 0.65^{\mathrm{a}}$ & $1.47 \pm 0.10^{\mathrm{a}}$ \\
G3 & $9.25 \pm 1.12^{\mathrm{d}}$ & $8.01 \pm 2.23$ & $6.84 \pm 1.72$ & $5.39 \pm 0.87$ & $1.25 \pm 0.10$ \\
G4 & $10.26 \pm 2.63^{\mathrm{b}}$ & $8.11 \pm 2.36$ & $6.62 \pm 1.54$ & $5.86 \pm 0.88$ & $1.34 \pm 0.13$ \\
G5 & $9.65 \pm 1.65^{\mathrm{d}}$ & $7.96 \pm 1.92^{\mathrm{c}}$ & $6.11 \pm 1.86^{\mathrm{c}}$ & $5.16 \pm 0.68^{\mathrm{c}}$ & $1.31 \pm 0.27$ \\
G6 & $9.76 \pm 1.38^{\mathrm{d}}$ & $7.98 \pm 1.29^{\mathrm{c}}$ & $5.97 \pm 1.93^{\mathrm{c}}$ & $4.95 \pm 0.83^{\mathrm{c}}$ & $1.16 \pm 0.17^{\mathrm{c}}$ \\
\hline
\end{tabular}

BAT, brown adipose tissue; G1, Normal; G2, High-fat diet (HFD) alone; G3, HFD + HCA (hydroxycitric acid); G4, HFD + 1\% MYE (Mulberry leaf + yacon); G5, HFD + 3\% MYE (mulberry leaf + yacon); G6, HFD + 5\% MYE (mulberry leaf + yacon). Each value represents the mean \pm S.D. $(\mathrm{n}=10$ per group)

${ }^{\mathrm{a}, \mathrm{b}}$ Significantly different from normal $(P<0.05,0.01) .{ }^{\mathrm{c}, \mathrm{d}}$ Significantly different from $\operatorname{HFD}$ alone $(P<0.05,0.01)$

Table 4. Effect of MYE (mulberry leaf + yacon tuber) on total body fat, protein and DNA concentration in normal and high-fat diet-fed rats

\begin{tabular}{cccc}
\hline \hline Treatment group & Body fat $(\mathrm{g})$ & Body protein $(\mathrm{mg} / \mathrm{dL})$ & DNA conc. $(\mu \mathrm{g})$ \\
\hline G1 & $39.0 \pm 6.4$ & $68.7 \pm 3.4$ & $396.6 \pm 34$ \\
G2 & $55.3 \pm 5.1^{\mathrm{a}}$ & $67.5 \pm 3.3$ & $427.3 \pm 67$ \\
G3 & $45.2 \pm 5.8^{\mathrm{c}}$ & $65.3 \pm 6.41$ & $451.3 \pm 71^{\mathrm{a}}$ \\
G4 & $49.2 \pm 5.9$ & $66.3 \pm 3.4$ & $449.3 \pm 49$ \\
G5 & $40.5 \pm 2.6^{\mathrm{c}}$ & $67.9 \pm 2.5$ & $469.1 \pm 48^{\mathrm{a}}$ \\
G6 & $40.1 \pm 1.9^{\mathrm{c}}$ & $65.3 \pm 3.3$ & $463.2 \pm 65^{\mathrm{a}}$ \\
\hline
\end{tabular}

BAT, brown adipose tissue; G1, Normal; G2, High-fat diet (HFD) alone; G3, HFD + HCA (hydroxycitric acid); G4, HFD + 1\% MYE (mulberry leaf + yacon); G5, HFD + 3\% MYE (mulberry leaf + yacon); G6, HFD + 5\% MYE (mulberry leaf + yacon). Each value represents the mean \pm S.D. $(\mathrm{n}=10$ per group)

${ }^{a}$ Significantly different from normal $(P<0.05)$. 'Significantly different from HFD alone $(P<0.05)$.

고지질군, 처리군 모두 증가하였다.

\section{고지방 처리 쥐의 당생성에 미치는 MYE의 영향}

$\mathrm{G} 2$ 의 글리코겐은 $\mathrm{G} 1$ 보다 $17.2 \%$ 유의미하게 감소하였 다 $(P<0.05)$ (Fig. 2). 그러나 $3 \% \mathrm{MYE}$ 그룹은 $\mathrm{G} 2$ 에 비해 $13.3 \%$ 증가하였다 $(P<0.05)$. G2의 G-6-P는 $\mathrm{G} 1$ 보다 $38.1 \%$ 증가하였다 $(P<0.05)$. 그러나 $\mathrm{G} 2$ 에 비해 $1 \%, 3 \%, 5 \% \mathrm{MYE}$ 처리군 및 $\mathrm{G} 3$ 은 $19.2 \%, 26.8 \%, 26.1 \%, 23.0 \%$ 감소하였다 $(P<0.05) . \mathrm{G} 2$ 의 G-6-PDH는 $\mathrm{G} 1$ 보다 $29.1 \%$ 낮아 유의성을 나타내었다 $(P<0.05)$. 그러나 $\mathrm{G} 2$ 와 비교하여 $\mathrm{G} 3$ 에서는 큰 차이가 없었다. 그러나 $\mathrm{G} 2$ 에 비해 $1 \%, 3 \%, 5 \% \mathrm{MYE}$ 그룹 은 $21.3 \%, 27.9 \%, 24.6 \%$ 증가하였다 $(P<0.05)$. G2의 Glucokinase는 G1보다 $47.3 \%$ 유의미하게 감소하였다 $(P<0.05)$. 그러나 $\mathrm{G} 2$ 에 비해 $1 \%, 3 \%, 5 \% \mathrm{MYE}$ 그룹과 $\mathrm{G} 3$ 은 $70.7 \%$, $65.3 \%, 71.4 \%, 48.5 \%$ 증가하였다 $(P<0.05)$.

\section{렙틴에 미치는 영향}

렙틴의 경우 $\mathrm{G} 2$ 가 일반 그룹보다 4배(305.6\%)나 크게 증가하였다 $(P<0.01)$ (Fig. 3). G3 및 모든 MYE 처리 그룹 이 $\mathrm{G} 1$ 에 비해 $155.6 \sim 250.0 \%$ 증가하였다 $(P<0.05 \sim 0.01)$. 그러나 $\mathrm{G} 2$ 에 비해 $1 \%, 3 \%, 5 \% \mathrm{MYE}$ 처리군 및 $\mathrm{G} 3$ 은 각각 $13.7 \%, 16.4 \%, 17.8 \%, 37.0 \%$ 로 감소하였다 $(P<0.05)$ (Fig. 3).

\section{고지방 처리 쥐의 간에 대한 병리학적 평가}

$\mathrm{G} 1$ 의 간 조직이 정상적인 모습을 나타낸 반면, $\mathrm{G} 2$ 은 지방 변화, 간엽의 괴사, Ito 세포의 다수, 간 손상 등을 나타내었다(Fig. 4). G2에서 간 손상이 9.4로 정량화되었으 며 $\mathrm{G} 1$ 에 비해 $\mathrm{G} 2$ 가 현저하게 손상을 나타내었다. 반면 간 손상은 $\mathrm{G} 2$ 에 비해 $\mathrm{G} 3$ 에서 개선되었다. 간 손상은 $\mathrm{G} 3$ 에서 3.4 로 정량화되었다. 처리 그룹의 간 손상은 $1 \%, 3 \%$, 
A

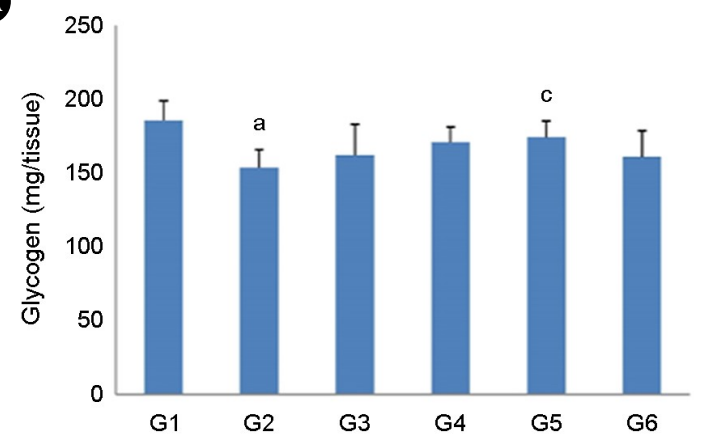

C

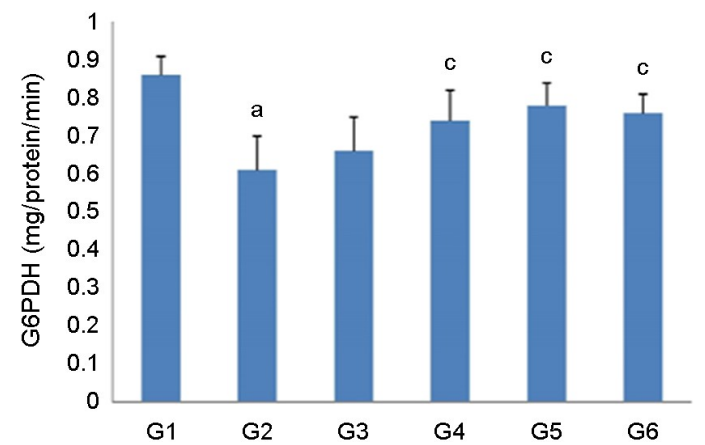

B

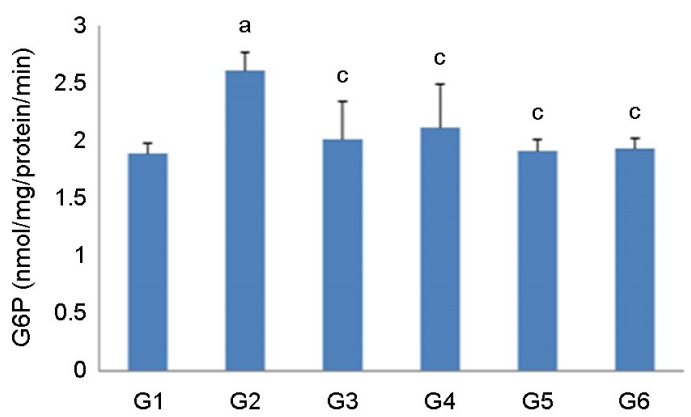

(D)

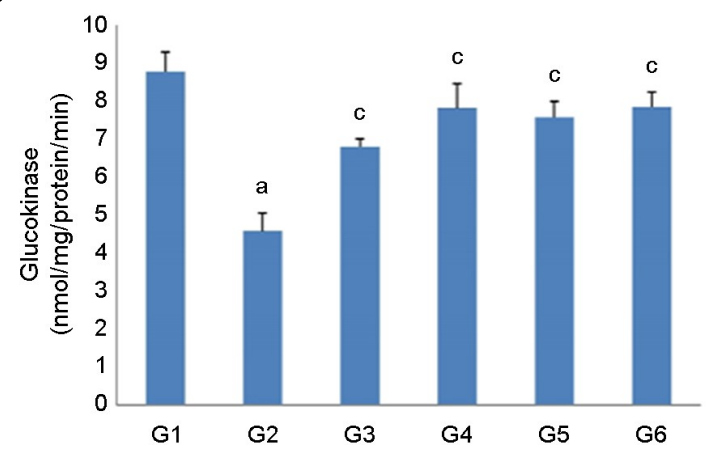

Fig. 2. Effect of MYE (mulberry leaf + yacon) on glycogenesis activities in high-fat diet-fed rats. (A) Glycogen; (B) G-6-P, glucose6-phosphatase; (C) G-6-PDH, glucose-6-phosphate dehydrogenase; (D) Glucokinase; ${ }^{a}$ Significantly different from normal $(P<0.05)$. ${ }^{\mathrm{c}}$ Significantly different from HFD alone $(P<0.05)$.

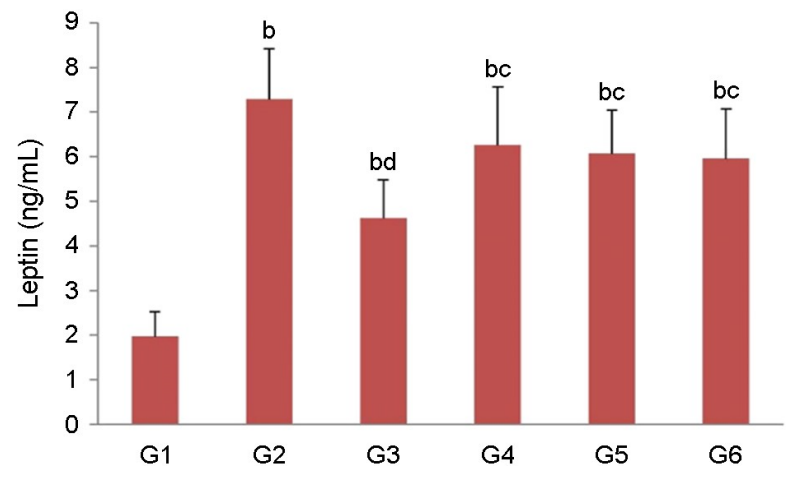

Fig. 3. Effect of MYE (Mulberry leaf + yacon) on leptin content in high-fat diet-fed rats. G1, Normal; G2, High-fat diet (HFD) alone; G3, HFD+HCA (hydroxycitric acid); G4, HFD + 1\% MYE (mulberry leaf + yacon); G5, HFD + 3\% MYE (mulberry leaf + yacon); G6, HFD + 5\% MYE (mulberry leaf + yacon). Each value represents the mean \pm S.D. ( $\mathrm{n}=10$ per group). ${ }^{\text {bignificantly }}$ different from normal $(P<0.01)$. ${ }^{\mathrm{c}, \mathrm{d}}$ Significantly different from HFD alone $(P<0.05, P<0.01)$

$5 \% \mathrm{MYE}$ 처리군, 대조군에서 각각 $2.0,0.8,1.2,0.2 \%$ 로 정량화되었다. 특히 $3 \% \mathrm{MYE}$ 처리군은 고지방 처리군에
비해 지질 유적, 지방 변화, Ito 세포가 크게 줄었다. 정량 적 분석의 결과 MYE 처리 그룹 중에서 $3 \% \mathrm{MYE}$ 가 가장 효과적인 것으로 나타났다(Fig. 3, Table 5).

\section{고 찰}

물 및 사료 섭취량 분석을 통해 $1 \%, 3 \%, 5 \% \mathrm{MYE}$ 처리 군은 $\mathrm{G} 1$ 에 비해 체중이 감소하였다. 이것은 지방대사의 개선과 혈액, 간의 체지방의 개선과 같은 효과에서 지방 분해로 인해 체중으로 전이되는 것을 억제한 것으로 간 주된다. 이런 체중의 감소는 이전에 뽕잎으로 실험한 결 과와 유사하였다(Kim et al., 1998, 1999). 1\%, 3\%,5\% MYE 처리 투여군은 $\mathrm{G} 1$ 에 비해 체중의 변화와는 달리 물과 사 료 섭취량 및 장기 체중에 유의미한 변화가 관찰되지 않 았다. 실험 기간 동안에 에너지 균형 변화를 측정하기 위 해서 실험 시작일과 종료일에 실험군의 체지방과 체단백 질의 내용물이 중요하다. 실험 종료일에 신체 구성의 내 용은 믹서를 사용한 건조 희생 생쥐의 균질화 방법으로 측정할 수 있지만 실험 시작일에서는 불가능하다. 이점을 
Table 5. Liver pathology scores of 8-week oral repeated dose MYE

\begin{tabular}{ccccccc}
\hline \hline $\begin{array}{c}\text { Treatment } \\
\text { group }\end{array}$ & $\begin{array}{c}\text { Cell } \\
\text { necrosis }\end{array}$ & $\begin{array}{c}\text { Destruction of } \\
\text { lobular structure }\end{array}$ & $\begin{array}{c}\text { Fatty } \\
\text { change }\end{array}$ & $\begin{array}{c}\text { Ito } \\
\text { cell }\end{array}$ & $\begin{array}{c}\text { Lesions } \\
\text { (maximum score) }\end{array}$ & Total \\
\hline G1 & 0 & 0 & 0.2 & 0 & 0 & 0.2 \\
G2 & 0 & 0.5 & 3.0 & 2.9 & 3.0 & 9.4 \\
G3 & 0 & 0.1 & 0.7 & 1.2 & 0.9 & 3.4 \\
G4 & 0 & 0.1 & 0.4 & 0.9 & 0.6 & 2.0 \\
G5 & 0 & 0 & 0.3 & 0.3 & 0.3 & 0.3 \\
G6 & 0 & 0 & 0.3 & 0.4 & 1.2 \\
\hline
\end{tabular}

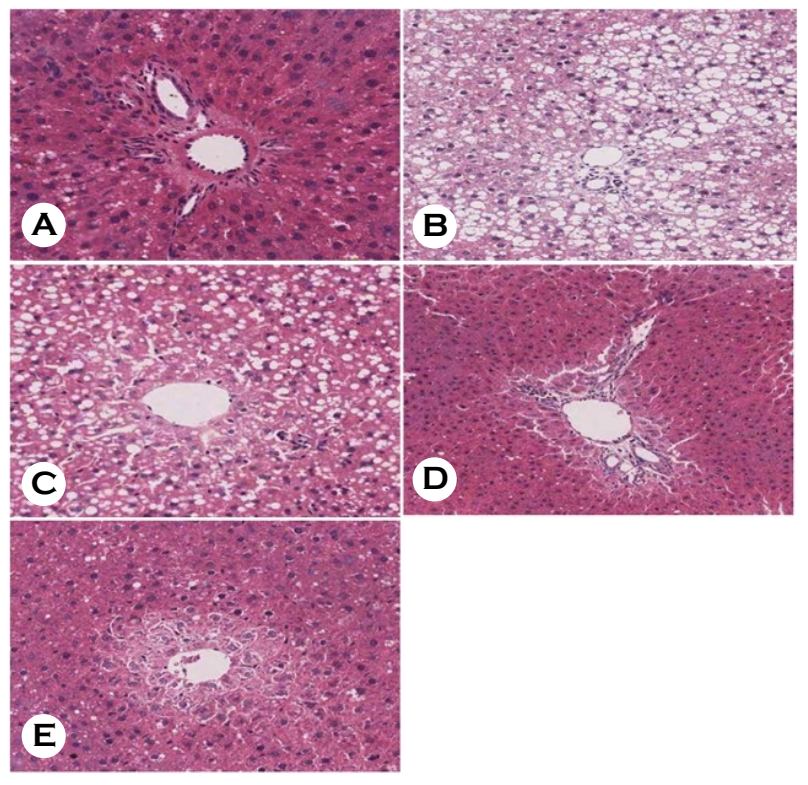

Fig. 4. Representative microscopic findings of the liver in rats. Fed normal diet (A), high-cholesterol diet alone (B), high-cholesterol diet containing $0.5 \%$ Hydroxycitric acid (C) 3\% MYE (Mulberry leaf + yacon) (D), 5\% MYE (mulberry leaf + yacon) (E). Note foamy hepatocytes distributed in centribolular region in $\mathrm{B}$ and more extensive hepatocytic change and congestion in $\mathrm{C}$, in comparison with minimal lesions in D, E. H\&E stain $(\times 200)$.

고려하여 실험 시작일에 유사한 체중의 생쥐 10 마리로 부터 얻은 데이터와 비교하여 실험 시작일에 체지방과 단백질의 함량을 계산하여 체성분 함량을 평가하고 있다 (Kawada et al., 1986; Cho and Shin, 1999, 2000). 쥐의 체중과 함께 체구성의 내용에는 차이가 있다. 본 연구에서는 체 중 차이를 줄이기 위해 비슷한 무게의 생쥐를 사용했다. 실험에서는 경막 지방조직, 체지방에 대한 지방 효과, 체 내 단백질 등 전염성 지방조직이 관찰되었다.

간에서 글리코겐의 함량은 $\mathrm{G} 1, \mathrm{G} 3$ 및 MYE 그룹과 비
교했을 때 $\mathrm{G} 2$ 에서 상당한 감소를 보인 반면 MYE 그룹 과 3\% MYE 비교했을 때 $3 \% \mathrm{MYE}$ 에서 현저하게 증가했 다 $(P<0.05)$. 이러한 결과는 $\mathrm{G} 2$ 의 고지질에 의한 $\mathrm{B}$ 세포 의 파괴가 인슐린의 배설을 감소시켜 간에서 글리코겐 증 상의 활성화를 감소시키고, 글리코겐을 분해하는 효소인 글리코겐 인산화 효소의 활성화를 증가시켰음을 나타낸 다(Wilcox, 2005). 이것은 간에서 글리코겐의 함량을 줄이 는 근거가 될 수 있다. 혈당 함량이 $3 \% \mathrm{MYE}$ 처리 그룹 에서 현저히 감소된 것은 간에서 글리코겐 함량이 증가 로 보여진다. G-6-P는 글리코겐의 분해와 포도당 생성을 위한 촉매 효소로 글루코르티코이드, 포도당, 지방산 등 을 증가시키며 인슐린, 종양 괴사 인자(TNF), 인터루킨-6 에 염증이 있을 경우에는 그 작용이 억제된다. 특히 고지 방 식단에 의한 제 2 형 당뇨병의 경우 G-6-P mRNA가 점 차 발달하여 당뇨 G-6-P의 활성화가 증가하고 단백질 키 나아제 및 인슐린 농도가 고지혈증과 함께 감소하였다 (Fu et al., 2013). 따라서 MYE 처리 그룹에서 G-6-P를 억제 하는 것이 그러한 결과를 뒷받침한다고 추정된다. G-6$\mathrm{PDH}$ 는 포도당 신진대사의 5 탄당 인산염의 초기 과정에 관여하는 효소로서 신체의 모든 세포에 존재하며 glutathione peroxidase (GSH-Px)에서 glutathione disulfide (GSSG) 를 glutathione $(\mathrm{GSH})$ 로 전환하는 데 필요한 $\mathrm{NADPH}$ 를 생 산하는 효소이기도 하다. 당뇨병과 고지질의 촉발제인 streptojotocin에 의한 제 2 형 당뇨병의 경우, G-6-PDH의 활 성화 감소는 $\mathrm{NADPH}$ 의 생산을 억제하는 것으로 알려져 있다. 본 연구에서는 G2에 비해 MYE 처리군에서 G-6$\mathrm{PDH}$ 의 현저한 증가가 관찰되었다. Glucokinase $(\mathrm{GK})$ 활성 화도 위에서 논의한 G-6-P와 G-6-PDH와 같은 결과를 보 였다. 특히 당뇨병의 경우 $\mathrm{GK}$ 의 활성화가 현저하게 감소 하는데, 이 연구에서도 이를 뒷받침하고 있다. 위에서 논 의된 당질과 관련된 지수의 결과에 근거하여, 테스트 물 
질이 당질성에 큰 영향을 미친 것으로 가정한다. 그러나 시험 물질의 용량 의존성은 관찰되지 않았다. 특히 당뇨 병의 경우 $\mathrm{GK}$ 의 활성화는 현저하게 감소해 당대사 이용 에 지장을 주고 있는데, 이 연구에서도 이를 뒷받침하고 있다. 위에서 논의된 당질과 관련된 지수의 결과에 근거 하여, MYE 처리 물질이 당대사에 큰 영향을 미친 것으로 판단된다. 그러나 시험 물질의 용량 의존성은 관찰되지 않았다.

$\mathrm{GST}$ 는 $\mathrm{G} 1$ 에 비해 $\mathrm{G} 2$ 에서 크게 증가한 반면, $\mathrm{G} 3$ 을 포함한 모든 MYE 그룹에서 현저하게 감소했다 $(P<0.05)$. $\mathrm{GST}$ 는 글루타티온의 티올을 체내에서 생산되는 전기적 독성 물질로 포착해 이 같은 독성 물질을 고갈시키는 것 으로 알려졌다. 위에서 관찰된 GST 감소는 GSH를 독성 물질로 포획하고 비만으로 인한 손상과 염증으로부터 간 을 보호하는 추출물에서 비롯되었다고 볼 수 있다.

Adipocytokine의 일종인 렙틴은 체중과 체지방 함량과 관련이 있으며, 특히 복부지방과 더 밀접하게 연관되어 있다(Considine et al., 1996). 체지방, 체형의 증가에 따라 지 방조직에서 분비되는 렙틴에 많은 초점이 맞춰져 있으며 식생활 연구의 변화도 렙틴과 연관시키고 있다(Havel et al., 1996). 그 결과 렙틴이 식이 섭취를 줄이고 에너지 소 비를 증가시키는 부분을 가지고 있다는 것이 보고되었다 (Pellymounter et al., 1995). 그런데 캘리포니아 주 Thousand Oaks에 있는 생명공학 회사인 암겐사(Amgen Inc.)는 비만 을 치료하는 약인 렙틴을 개발했지만, 비만 환자에게 $20 \%$ 에 효과를 나타내는데 그쳤다(Singhal et al., 2002). 최근 동 맥경화증 발생의 렙틴 역할에 대해 보고되었으며, 렙틴은 심혈관 질환의 위험요소라는 의견이 있다(Cooke and Oka, 2002). 본 연구에서 혈액 내 렙틴 농도는 과산화물 형성 을 위한 지표에서 양의 관계를 보여주었으며 혈액 내 지 질 농도와도 매우 관련이 있었다. 따라서 혈액 속의 렙틴 의 농도는 비만의 정도를 객관적으로 보여주는 매우 중요 한 지수로 여겨진다. 혈류 내 렙틴은 체지방 함량과 체질 량 지수와의 뚜렷한 양의 상관관계를 나타내었기 때문에 비만군은 혈청 렙틴 수준에서 정상군보다 현저히 높게 나 타난다(Considine et al., 1996; Kim and Sung, 2000). 이는 본 연구의 결과를 뒷받침하지만, MYE가 렙틴의 수준을 어떻 게 향상시키는지 정확히 알려지지 않았다. 지질대사 개선 이나 플라보노이드에 의한 항산화 효과 때문일 수 있으 나 정확한 메커니즘에 대한 연구가 필요하다.

지질 변화는 보통 동물의 약 10 15\%에서 관찰된다. 반 대로 고농축성 핵이 있는 간세포, 세포질의 변화, 중성지
방의 지방 변화 등은 고지방 식단군에서 주목되었다. 특 히 많은 Ito 세포가 관찰되었다. 이에 대한 정량적 평가는 간엽의 파괴 때문에 0.5 로 평가되었다. 지방 변화, Ito 세 포, 그리고 모든 병변이 평가된 9.4의 가장 높은 점수를 받은 모든 동물에서 관찰되었다. 또 $\mathrm{G} 2$ 는 세포의 불규칙 한 크기와 형태, 세포 크기의 다양성, 단핵구 침투 등 전 형적인 조직학적 변화를 보여주었다. $1 \%$ 와 $5 \%$ 의 $\mathrm{MYE}$ 물질에 대한 정량적 평가는 각각 2.0 과 1.2 로, MYE 처리 그룹이 $\mathrm{G} 2$ 뿐만 아니라 $\mathrm{G} 3$ 과 비교해 현저히 개선된 것으 로 나타났다. 특히 $3 \%$ 의 MYE 처리 그룹은 지방세포와 Ito 세포의 현저한 감소를 보였다. 간도 $\mathrm{G} 1$ 과 비슷하게 개선되었다. 이는 고지방식이를 했기때문에 간의 경우 지방이 많이 축적되어 간 무게 증가하는 것이 일반적인 현상임에도 불구하고 간 지방의 증가가 늘어나지 않는 것은 간 조직의 미토콘드리아에서 베타-산화로 지질의 분해가 활발했을 것으로 판단된다(Nassir et al., 2015). 또한 본 실험에서 관찰된 결과는 지질대사와 관련된 효소의 생화학적 작용과 대사장애의 개선에서 비롯되었다고 판 단된다. 본 연구 결과 뽕잎과 야콘에서 추출한 MYE 처 리군은 전반적으로 $\mathrm{HCA}$ 처리군에 비해 간, 폐, 신장, 고 환을 포함한 장기 무게를 보존하고, 신장과 부고환, 내장 지방에 있어서 비만을 억제하는 효과를 나타내었다. 그러 나 $\mathrm{HCA}$ 는 체중 감량 또는 지방 연소의 역할을 하지는 않 으며, 소화기 통증을 유발할 수 있다는 점에서 소화기 질 환을 가진 환자에게 처방은 주의해야 한다(Yamada et al., 2007)는 점에서 뽕잎과 야콘 추출물이 $3 \%$ 정도로도 지방 축적을 막는 역할을 보여주어 천연 물질의 항비만제 개 발에 기초가 될 수 있다. 뽕나무 뿌리의 Mulberroside A 성 분이 항지질성 비만에 도움이 되는 것으로 보고(Jo et al., 2014)되어 뽕나무에 대한 많은 연구가 기대된다.

\section{ACKNOWLEDGEMENTS}

본 연구는 대전대학교 2016년 교내 연구비에 의해 수 행되었다(This work was supported by research funds of Daejeon University in 2016).

\section{CONFLICT OF INTEREST}

The authors declare that they have no conflict of interest.

\section{REFERENCES}

Atkinson RL. Use of drugs in the treatment of obesity. Annu Rev 
Nutr. 1997. 17: 383-403.

Baginski ES, Foa PP, Zak B. Glucose-6-phosphatase. In: Methods of enzymatic analysis. 2. (Bergmeyer HU. Ed). 1983. pp 876 -880. Academic Press; NY, USA:

Carmichael AR. Treatment for morbid obesity. Postgrad Med J. 1999. 75: 7-12.

Chen HL, Lu YH, Lin JJ, Ko LY. Effects of fructooligosaccharide on bowel function and indicators of nutritional status in constipated elderly men. Nutr Res. 2000. 20: 1725-1733.

Cho JJ, Shin HJ. Body-fat suppressive effects of capsaicin through $\beta$-adrenergic stimulation in rats fed a high-fat diet. Korean $\mathrm{J}$ Nutr. 1999. 32: 533-539.

Cho JJ, Shin HJ. Sensory evaluation and changes in physiochemical properties, and microflora and enzyme activities of pumpkinadded kochujang. Korean J Food Sci Technol. 2000. 32: 851 -859 .

Considine RV, Sinha MK, Heiman ML, Kriauciunas A, Stephens TW, Nyce MR, Ohannesian JP, Marco CC, McKee LJ, Bauer TL, Caro JF. Serum immuno-reactive-leptin concentrations in normal-weight and obese humans. N Engl J Med. 1996. 334: 292-295.

Cooke JP, Oka RK. Dose leptin cause vascular disease? Circulation. 2002. 106: 1904-1905.

DeMoss RD. Kinases in Leuconostoc mesenteroides. J Bacteriol. 1968. 95: 1692-1697.

$\mathrm{Fu}$ Z, Gilbert ER, Liu, D. Regulation of insulin synthesis and secretion and pancreatic beta-cell dysfunction in diabetes. Curr Diabetes Rev. 2013. 9: 25-53.

Fujimoto T, Nomura T. Components of root bark of cudrania tricuspidata 3. Isolation and structure studies on the flavonoids. Planta Med. 1985. 51: 190-196.

Guallar E, Stranges S, Mulraw C, Appel LJ. Enough is enough: Stop wasting money on vitamin and mineral supplements. Ann Intern Med. 2013. 159: 850-851.

Hara H, Miwa I, Okuda J. Inhibition of rat glucokinase by alloxan and ninhydrin. Chem Pharm Bull. 1986. 34: 4731-4737.

Havel PJ, Kasim-Karakas S, Dubuc GR, Mueller W, Phinney SD. Gender differences in plasma leptin concentrations. Nat Med. 1996. 2: 949-950

Hirano T. Pathophysiology of diabetic dyslipidemia. J Atheroscler Thromb. 2018. 25: 771-782.

Jee SH, Sull JW, Park J, Lee SY, Ohrr H, Guallar E, Samet JM.

Body-mass index and mortality in Korean men and women. N Engl J Med. 2006. 355: 779-787.

Jo SP, Kim JK, Lim YH. Antihyperlipidemic effects of stilbenoids isolated from Morus alba in rats fed a high-cholesterol diet. Food Chem Toxicol. 2014. 65: 213-218.

Kawada T, Hgihara K, Iwai K. Effects of capsaicin on lipid metabolism in rats fed a high fat diet. J Nutr. 1986. 116: 1272-1278.

Kereiakes DJ, Willerson JT. Metabolic syndrome epidemic. Circulation. 2003. 13: 1552-1553.

Kim CH, Choi TM, Chang SG, Hong SY. Palsma homocysteine, folate and vitamin B concentrations in coronary artery disease. J Kor Cir. 1998. 28: 516-524.

Kim IJ. Autoantibodies against oxidized LDLs and atherosclerosis in type 2 diabetes. Diabetes Research Digest. 2005. 2: 70-71.

Kim SS, Oh HY, Kim HR, Yang JS, Kim DS, Sheen YY, Choi KH. Effect of biphenyl dimethyl dicarboxylate on cytochrome P450 1A1 and 2B1 and CCl4-induced hepatotoxicity in rat liver. Yakhak Hoeji. 1999. 43: 827-833.

Kim MH, Sung CJ. The study of relationship among serum leptin. nutritional status, serum glucose and lipids of middle-school girls. Kor J Nutr. 2000. 33: 49-58.

Kopelman P. Health risks associated with overweight and obesity. Obes Rev. 2007. 8: 13-17.

Lim TK. Edible medicinal and non medicinal plants. 2015. pp 717 -734. Springer, Dordrecht.

Lowry OH, Rosebrough NJ, Farr AL, Randall RJ. Protein measurement with the folin phenol reagent. J Biol Chem. 1951. 193: 265-275.

Ministry of Health and Welfare. National Health Interview Survey (NHIS). National Center for Health Statistics, Centers for Disease Control and Prevention; Sejong, Korea. 2018. pp 71 -72 .

Murat JC, Serfaty, A. Simple enzymatic determination of polysaccharide (glycogen) content of animal tissue. Clinical Chemistry. 1974. 20: 1576-1577.

Nassir F, Rector RS, Hammound GM, Ibdah JA. Pathogenesis and prevention of hepatic steatosis. Gastronterol Hepatol (NY). 2015. 11: 167-175.

Ogden CL, Yanovski SZ, Carroll MD, Flegal KM. The epidemiology of obesity. Gastroenterology. 2007. 132: 2087-2102.

Pellymounter MA, Cullen MJ, Baker MB, Hecht R, Wmters D, Boone T. Effects of the obese gene product on body weight regulation in ob/ob mice. Science.1995. 269: 540-543.

Pi-Sunyer XF. Medical hazards of obesity. Ann Intern Med. 1993. 119: 655-660.

Prentice AM. Obesity and its potential mechanistic basic. Brit Med Bull. 2001. 60: 51-67.

Russo D, Valentao P, Andrade PB, Fernandez EC, Milella L. 
Evaluation of antioxidant, antidiabetic and anticholinesterase activities of Smallanthus sonchifolius landraces and correlation with their phytochemical profiles. Int J Mol Sci. 2015. 16: 17696-17718.

Singhal A, Farooqi IS, Cole TJ, O'Rahilly S, Fewtrell M, Kattenhorn M, Lucas A, Deanfield J. Influence of leptin on arterial distensibility: a novel link between obesity and cardiovascular disease. Circulation. 2002. 106: 1919-1924.

Yamada T, Hida H, Yamada Y. Chemistry, physiological properties, and microbial production of hydroxycitric acid. Appl Microbiol Biotechnol. 2007. 75: 977-982.

Weledji, EP. Overview of gastric bypass surgery. Int J Sur Open.
2016. 5: 11-19.

WHO. The Asia pacific perspective: redefining obesity and its treatment. Geneva. Ref. Type, Report. 2000.

Wilcox G. Insulin and insulin resistance. Clin Biochem Rev. 2005. 26: 19-39.

https://doi.org/10.15616/BSL.2020.26.2.75

Cite this article as: $\mathrm{Lim} \mathrm{Y}, \mathrm{Oh} \mathrm{JH}$, Park UK, Huh MK, Hwang SY. Anti-obesity Effects of Mulberry Leaf and Yacon Extract in Obese Rats. Biomedical Science Letters. 2020. 26: 75-84. 